\title{
Prison Reforms System and Inmate's Welfare in Nigeria
}

Opafunso ZO* and Adepoju OO

School of Management Technology, Federal University of Technology, Akure, PMB 704, Ondo State, Nigeria

*Corresponding author: Opafunso ZO, School of Management Technology, Federal University of Technology, Akure, PMB 704, Ondo State, Nigeria, Tel: +2348033505007, +2348032244425; E-mail: zopafunso@yahoo.com

Received date: February 16, 2016; Accepted date: March 25, 2016; Published date: March 31, 2016

Copyright: (c) 2016 Opafunso ZO, et al. This is an open-access article distributed under the terms of the Creative Commons Attribution License, which permits unrestricted use, distribution, and reproduction in any medium, provided the original author and source are credited.

\begin{abstract}
The dilapidation state of the Nigeria prisons demonstrates a condition that cannot guarantee the reformatory process of the inmates. This can be attributed to the disregard for the welfare of the inmates and failure to implement the prison reforms recommendations. The paper examined the effectiveness of prisons reforms on the welfare of inmates in Ado Ekiti and Olokuta prisons in Ekiti and Ondo States respectively. The study employed a descriptive survey research design with the use of a structured questionnaire to obtain information from the inmates. Multi stage sampling technique was adopted to select the respondents (inmates) from the two prisons. Data for this study were analysed using descriptive statistics and chi square to test the hypothesis formulated for the study. The study revealed that poor administration of the criminal justice systems and unethical practices of the Nigeria police force in Nigeria resulting to high number of inmates awaiting trials are the major causes of overcrowding of the prisons. Therefore, overcrowding constitute a major threat to the welfare of the inmates. In addition the study revealed that prison reforms have a significant impact on the welfare of the inmates in Ado Ekiti and Olokuta. The study recommended government intervention in the implementation of the previously recommended prison reforms, constant supervision of the prisons by the Minister of interior and allocation of funds for provision of infrastructure to cater for the needs of the Nigeria Prison Service.
\end{abstract}

Keywords: Prison reforms; Amnesty; Congestion; Inmate; Welfare

\section{Introduction}

Prisons are public institutions established by government for the rehabilitation and reformation of individual's offenders who are at breach of the law. Prison is viewed as a physical structure within a specific geographical location which affords a unique kind of social environment that is different from the larger society where people live according to specialized conditions [1]. All over the world, prisons are established to serve as rehabilitation and reformatory institutions with the ultimate goal of re-orientating and reforming inmates, so that they could come out as useful members of society [2]. This institution was established to support criminal justice system in which criminal offences are confined pending the final conviction decision is taken to determine the guilt or innocence of the accused person. Subsequently, incarceration in the event of being found guilty is implemented. People who have been charged or convicted of one criminal offence or more are expected to get re-oriented and become better to live in the society when they leave the prison [2].

Historically, prisons originated from the English workhouse under the Tudor family in the 1550s and afterward a royal family palace known as Bride well in England was converted into workhouse prisons in 1570. This workhouses or prisons were badly maintained and the wardens were often negligent to prisoners needs. Several prisoners died of typhus, malnutrition and other means. In 1777, the state of the prisons in England was criticized as being unorganized, unhygienic and importantly as a means of punishment rather than rehabilitation. This also extended to the American prisons and reformation of prisons agenda in various societies started to form.
The call for the reform of the Nigeria prison services is becoming a perennial thing as successive governments have failed to do anything tangible in that direction $[3,4]$. The prison system in Nigeria like every others, is modeled after the British system which dates back to the colonial era. It is a system that lays emphasis on punishment and deterrence [5]. The Nigerian prison system was established on three legislative frame works which operates side by side. These include:

- The penal code and the accompanying criminal procedure code cap 81 laws of the federation 1990 (CPC);

- The criminal code and the accompanying criminal procedure Act Cap 80 laws of the federation (CPA) and

- The Sharia penal legislation in 12 Northern States of Nigeria which is only applicable to Muslims.

All prisons in Nigeria are managed by the Nigerian Prisons Service (NPS), a parastastal under the Ministry of Interior, headed by a Controller General of Prisons, who presides over the administration of all prison facilities. The NPS is also an important arm of the criminal justice system solely charged with the responsibility of taking into custody all those who have been interred to correct them for eventual release and to help integrate them back into the society [5]. In the operations of Nigerian prisons, CAP 366 Laws of the Federation of Nigeria 1990, charges the prisons, among other things to perform the following responsibilities:

- To take into lawful custody all those certified to be so kept by courts of competent jurisdiction;

- To produce suspects in courts as at when due;

- To identify the causes of anti-social behavior;

- To set in motion mechanisms for their treatment;

- To train inmates for eventual reintegration into society as normal law abiding citizens on discharge and 
- To administer prisons farms and industries for this purpose; and in the process generate revenue for the government [5].

Several writers have attested to the neglect of the prisons in attaining the purpose of its establishment as stated in the Law, instead the prison system is accused of hardening inmates, subjecting them to horrible and degrading conditions, given punishment exceeding the crimes committed; in the process, rendering inmates physically and psychologically damaged in an uncaring environment [5]. According to a recent report by Amnesty International, more than three of every five prison inmates in Nigeria have not been convicted of any offence; instead, they wait years for their trial in appalling conditions [6]. This fact was corroborate by the immediate past Comptroller-General of the Nigerian prisons service (NPS), Mr. Olusola Ogundipe, while testifying during a public hearing on the proposed prisons amendment bill.

The major problem confronting the Nigeria prison system is congestion caused by persons awaiting trial in prisons across the country. The figure of awaiting trial persons is rising daily and it is becoming an embarrassment to the nation [3]. Ogundipe [7] revealed that pre-trial detainees now constitute about 80 per cent of the prison population. Most of them, according to the writer are held for minor offences, for which bail is available. He added that for many of the detainees, there are no case files. Furthermore, awaiting trial persons (ATPs) is estimated as 30,000 persons, representing over 65 percent of the estimated prisoner's population of 46,000 [5,8]. The Aftermath of the prevalence ATPs is an anomaly which at best frustrates crime prevention and control as they are mixed up with the convicts who might end up influencing them for negatively into becoming hardened criminals [9].

\section{Problem Statement}

Various reforms programs have been proposed towards improving the Nigeria prisons. Nevertheless, the menace of the dilapidation state of the Nigerian prisons still poses a concern and requires urgent attention. Nigerian prisons are characterized by overcrowding, widespread of disease, poor ventilation, poor feeding and poor medical attention. Several writers have identified congestion and nonimplementation of prison reforms recommendations as the major challenges confronting the Nigerian prisons $[5,10,11]$. A report of a 12man presidential committee on prison decongestion revealed that 29,372 inmates out of 41,524 inmates are awaiting trial. Many cells meant to accommodate about 50 inmates were found to accommodate about 150 inmates; all cramped together [12]. According to Njoku [9], the Kirikiri Maximum Security Prison in Lagos, is overcrowded by 250 percent. The prison, which was built for 956 inmates, is today occupied by over 2,600 inmates of which majority of the inmates awaiting trial [9]. Amnesty International [8] also exposed the appalling state of Nigeria's prison system. The report revealed how at least 65 percent of Nigeria's inmates have never been convicted of any crime, with some awaiting trial for up to ten years. In addition, the report discovered that most prisoners are too poor to afford a lawyer and how the appalling prison conditions have seriously damaging effect on the mental and physical health of the inmates. According to the National Assembly Legislative Digest [13] overcrowded prisons inexorably lead to inmates being exposed to improper health conditions that result in the spread of epidemics likely to cause death such as tuberculosis, HIV/AIDS and diabetes. Based on these identified problems, the researcher decided to assess the impact of prison reforms on the welfare of inmates in Ekiti and Ondo States. Other specific objectives are to investigate the causes of congestion in Ado-Ekiti and Olokuta
Prison, effect of congestion on the inmates and the impact of the prison reforms on the welfare of the inmates.

\section{An Evaluation of the Reforms Programs in the Nigeria Prison System}

The Nigeria prison system in Nigeria has experienced various reforms programs initiated by the government. These reforms programs are expected to address the problem of congestion, overcrowding, improve the living conditions of inmates and ensure the proper rehabilitation of the inmates. The philosophy of the Nigerian Prison Service is that treatment and rehabilitation of offenders can be achieved through carefully designed and well-articulated administrative, reformative and rehabilitative programs aimed at inculcating discipline, respect for law and order, and regard for the dignity of honest labor [12]. The introduction of the reforms programs can be traced the Obasanjo's regime in June 2001, when a proposition was made to review the prisons laws, rehabilitate inmates, train prison's personnel and revive the prison system with the Prison Reforms Program. According to Obioha [10], the preliminary steps taken to actualize the mission to reform the prisons, include the establishment of several working groups and committees on prison reforms with different mandates and terms of reference from 2000-2007. The agenda set for most of the committees and groups that were involved in the task of the Nigeria prisons reforms focused in all or at least one of the following pressing areas of decadence, namely congestion and overcrowding, physical/infrastructure facilities, treatment of inmates, logistics and transportation system, and skills development [10]. According to Amnesty [8], several working groups and committees on prison reforms have been established since the year 2000. These include:

The National Working Group on Prison Reform and Decongestion reviewed 144 prisons and revealed in its 2005 report that the population of Nigerian prisons over the previous 10 years had totaled between 40,000 and 45,000 inmates, most of them concentrated in the state capitals. Of those, 65 percent were awaiting trial.

The Inter-Ministerial Summit on the State of Remand Inmates in Nigeria's Prisons was established in 2005 to review the report of the previous Working Group on Prison Reform. It recommended the Federal Government respond to the problem of inmates awaiting trial, pay more attention to rehabilitation, and address the issue of the large number of inmates awaiting trial due to the shortage of due to the shortage of defense counsel.

In 2006, the Presidential Committee on Prison Reform and Rehabilitation was established. This committee recommended improving the conditions of service of prison and police officials, and addressing the issues of prison congestion and the large number of prisoners awaiting trial. When the then President Obasanjo received the committee's report; he said that the Federal Government would implement its recommendations.

The presidential commission on the reform of the administration of justice (PCRAJ), established on 16 March 2006 to review the administration of justice in Nigeria and propose sustainable reforms, expressed concern that imprisonment was being overused, including in cases of the non-violent persons suspected of minor offences.

The Committee on the Harmonization of Reports of Presidential Committees Working on Justice Sector Reform reiterated in April 2007 the recommendations of the PCRAJ. 
Page 3 of 6

In spite of these reform programs, the prison system is still faced with several problems which constantly create an environment of threat to the wellbeing of the inmates. Report shows that Nigerian government has, on several occasions, stated its willingness to reform the criminal justice system, nevertheless, these recommendations have not been implemented [8]. Instead, the government has simply set up new committees and commissions to study review and harmonize the previous recommendations. Also, recent report still shows that there is overcrowding in the prisons despite the introduction of amnesty and allocation of capital funds to resolve the problem of congestion. Consequently, the present state of the Nigeria prison reflects negligence and disregard of the welfare of the prisoners.

\section{Methodology}

The study adopted the descriptive survey research design to investigate the Impact of Prison reforms on the welfare of the inmates in Ado-Ekiti Prison and Olokuta Prison Akure. The population of the study includes all categories of prisoners in both prisons: Ado-Ekiti Prison and Olokuta Prison Akure. Multi-stage sampling method was adopted to select the respondents (inmates) from both Ado-Ekiti and Olokuta prisons using the cluster, strata and stratified sampling method including incorporated the five categories of sentences (short term, long term, ATP, Lifer and Final lock-up). One hundred (100) respondents were systematically selected from the two prisons this was done through the division of the total number of inmates by 8 .

A validated 35 items questionnaire comprising of 5 items in section $\mathrm{A}$ and 30 items in section B were used to obtain information from the target respondents. The questionnaire was designed in a simple and unambiguous language. The first part (section A) dealt with the demographic data of the inmates while section B consisted of items which were used to assess the impact of prison reforms on the welfare of the inmates. The printed questionnaires were administered by the researcher and field assistants. Simple frequency was used to present the data and represented by percentages. The questionnaires retrieved from the field were analyzed using SPSS package. Furthermore, the research hypotheses earlier formulated in the study were analyzed with chi-square, one of the non-parametric tests of significance.

\section{Research Questions}

The following questions were raised to guide the study:

- What are the causes of congestions in the Nigerian prisons?
- What are the consequences of congestion in the Nigerian Prison?

- To what extent has the prison reforms impacted on the welfare of the inmates in the Nigerian prisons?

\section{Research Hypothesis}

The study tested the following hypotheses to guide the study:

- $\mathrm{H}_{0}$ - Delay justice have no significant impact on prison congestions

- $\mathrm{H}_{1}$ - Delay justice have a significant impact on prison congestions

- $\mathrm{H}_{0}$ - Prison reforms have no significant impact on the welfare of the inmates

- $\mathrm{H}_{1}$ - Prison reforms have a significant impact on the welfare of the inmates

\section{Data Presentation and Analysis}

The questionnaire revealed that 96 (96\%) of the respondents were male while their female counterpart represents only 4 (4\%). The data reveals that there are more males than the female in the selected prisons, i.e. most of the prison inmates in Nigeria are men. Two third 75 (75\%) of the inmates ages falls between $30-50$ years, 20 (20\%) of the respondent falls below 30 years and $5(5 \%)$ above 50 years. Majority of the $(75 \%)$ inmate's age's falls between the active periods of their life. Educational qualification analysis revealed that 25 (25\%) of the respondent has educational qualification above secondary school level, $64(64 \%)$ possessed at least primary educational background while 11 (11\%) has no formal education. This result also revealed that majority $89(89 \%)$ of the inmates has a form of formal education. $77(77 \%)$ of the inmates falls under ATP, $16(16 \%)$ of the inmates have a long term sentence, $6(6 \%)$ has short term sentence and $1(1 \%)$ has a Lifer. The occupation analysis of the inmates revealed that 54 (54\%) of the inmates were involved in private trade which include artisan, farming and other self-employed businesses, 25 (25\%) were students and 22 (21\%) were public servant. This revealed that majority (54\%) of the inmates were gainfully employed.

\section{Result and discussion of findings}

The three research question raised for this study was analyzed below:

Distribution of respondents stating the factors contributing to congestion in the Prisons

\begin{tabular}{|l|l|l|l|l|l|}
\hline \multirow{2}{*}{$\mathbf{S} / \mathbf{N}$} & \multirow{2}{*}{ Causes } & \multicolumn{2}{|c|}{ Responses } & \multicolumn{2}{|c|}{ Total \% } \\
\cline { 3 - 7 } & & Strongly Agree & Strongly Disagree & Undecided \\
\hline 1 & Poor Administration of criminal justice & $97 \%$ & $2 \%$ & $1 \%$ & 100 \\
\hline 2 & Awaiting Trial & $96 \%$ & $2 \%$ & $2 \%$ & 100 \\
\hline 3 & Police Officers & $89 \%$ & $2 \%$ & $9 \%$ & 100 \\
\hline 4 & Delay Justice & $96 \%$ & $2 \%$ & $2 \%$ & 100 \\
\hline
\end{tabular}

Table 1: Answer to Question 1 raised in this study showing the causes of Congestion in the Prisons.

Table 1 shows that majority, 97\%, 96\%, $89 \%$ and $96 \%$ of the respondents affirmed that poor administration of the criminal justice systems, awaiting trial, police officer and delay justice are the causes of congestion in the prison. The result indicates that criminal justice systems in Nigeria is poorly administered thereby leading to increase 
in inmates awaiting trials and delay in justice which is a major contributed to prison congestion in Nigeria.

\begin{tabular}{|l|l|l|l|l|}
\hline \multirow{2}{*}{ S/N } & \multirow{2}{*}{ Consequences of Congestion in the Prisons } & \multicolumn{2}{|c|}{ Responses } \\
\cline { 3 - 6 } & & Strongly Agree & Strongly Disagree & Undecided \\
\hline 1 & Untimely Death of Inmates & 93 & 2 & 5 \\
\hline 2 & Negative impact on the Health of the Inmates & 93 & 2 & 5 \\
\hline 3 & Expose Inmates to environmental Hazard & 93 & 2 & 5 \\
\hline 4 & Negative impact on the welfare of the inmates & 93 & 2 & 100 \\
\hline
\end{tabular}

Table 2: Distribution of respondents stating the consequences of congestion in the prisons.

Table 2 shows that majority, 93\%, 93\%, 93\% and 93\% of the respondents affirmed that untimely death, negative impact on the Health of the inmates, expose to environmental Hazard and Negative impact on the welfare of the inmate are the consequences of congestion in the prisons. The result indicates that congestion of the prison has a negative impact on the inmates.

\begin{tabular}{|l|l|l|l|l|l|}
\hline \multirow{2}{*}{$\mathbf{S} / \mathbf{N}$} & \multirow{2}{*}{ Causes } & \multicolumn{2}{|c|}{ Responses } & \multicolumn{2}{|c|}{ Total\% } \\
\cline { 3 - 6 } & Strongly Agree & Strongly Disagree & Undecided \\
\hline 1 & $\begin{array}{l}\text { Establishment of more prisons would } \\
\text { improve the welfare of the inmates }\end{array}$ & 63 & 3 & 34 & 100 \\
\hline 2 & $\begin{array}{l}\text { Granting of Amnesty by State } \\
\text { Government would reduce congestion } \\
\text { in the prison }\end{array}$ & 91 & 2 & 7 & 100 \\
\hline 3 & $\begin{array}{l}\text { Prison Reform would alleviate the } \\
\text { problems of inmates }\end{array}$ & 91 & 2 & 7 & 100 \\
\hline 4 & $\begin{array}{l}\text { Prison Reform would improve the } \\
\text { prisons facilities and the welfare of the } \\
\text { inmates }\end{array}$ & 95 & 1 & 4 & 100 \\
\hline
\end{tabular}

Table 3: Showing the Distribution of Respondents stating the impact of Prison Reform on the Welfare of the inmates.

Table 3 shows that majority, 63\%, 91\%, 91\% and 95\% of the respondents affirmed that establishment of more prisons, granting of amnesty by state government, improvement in the prisons facilities and the prisons reforms would improve the welfare of the inmate. The result indicates that prison reforms have a significant impact on the welfare of the inmates.

\section{Hypotheses 1}

$\mathrm{H}_{0}$ - Delay justice have no significant impact on prison congestions in Nigeria.

$\mathrm{H}_{1}$ - Delay justice have a significant impact on prison congestions in Nigeria.

\begin{tabular}{|l|l|l|l|l|l|}
\hline Items & $\mathbf{N}$ & DF $(\mathbf{V})$ & $\mathbf{X}^{2}{ }_{C}$ & $\mathbf{X}^{2}{ }^{2}$ & $\mathbf{P}$ \\
\hline Strongly Agree & 96 & 4 & 10.017 & 9.488 & Sig \\
\hline Strongly Disagree & 2 & & & \\
\hline Undecided & 2 & & & \\
\hline $\mathbf{P}<0.05$ & 100 & & & \\
\hline
\end{tabular}

Table 4: Chi-square test measuring the relationship between delay justice and prison congestions in Nigeria.

Table 4 present the relationship between delay justice and prison congestions in Nigeria. Form the table, $\mathrm{X}^{2}$ calculated (10.017) is greater than $\mathrm{X}^{2}$ table value $(9.488)$ i.e. $\mathrm{X}_{\mathrm{c}}^{2}>\mathrm{X}_{\mathrm{t}}{ }_{\mathrm{t}}$ at 0.05 level of significance with 4 degrees of freedom. The alternative hypothesis $(\mathrm{Hi})$ is accepted. Therefore, delays in justice have a significant impact on prison congestions in Nigeria. The result of the hypothesis tested revealed that there is a significant relationship impact of delay justice on prison congestion in Nigeria. 
Page 5 of 6

\section{Hypotheses 2}

$\mathrm{H}_{0}$ - Prison reforms has no significant impact on the welfare of the inmates in Nigeria.

$\mathrm{H}_{1}$ - Prison reforms have a significant impact on the welfare of the inmates in Nigeria.
Table 5 present the relationship between prison reforms and the welfare of the inmates in Nigeria Form the table, $\mathrm{X}^{2}$ calculated (10.879) is greater than $\mathrm{X}^{2}$ table value (9.488) i.e. $\mathrm{X}^{2}{ }_{\mathrm{c}}>\mathrm{X}^{2}{ }_{\mathrm{t}}$ at 0.05 level of significance with 4 degrees of freedom.

\begin{tabular}{|l|c|c|c|c|c|}
\hline Items & N & DF (V) & X2C & X2t & P \\
\hline Strongly Agree & 94 & 4 & 10.876 & 9.488 & Sig \\
\hline Strongly Disagree & 2 & & & & \\
\hline Undecided & 4 & & & & \\
\hline P $<0.05$ & 100 & & & \\
\hline
\end{tabular}

Table 5: Chi-square test measuring the relationship between prison reforms and the welfare of the inmates in Nigeria.

The alternative hypothesis $(\mathrm{Hi})$ is accepted. Therefore, prison reforms have a significant impact on the welfare of the inmates in the Nigeria prisons. The result of the hypothesis tested revealed that there is a positive impact of prison reforms on the welfare of the inmates in Nigeria.

\section{Discussion of Findings}

The study of prison reform on the welfare of inmates with reference to the inmates in Ado Ekiti prison and Olokuta prison in Ekiti and Ondo state revealed that prison reform has a significant impact on the welfare of the inmates. From the demographic analysis, the result shows that majority of the inmates $96 \%$ were male while $4 \%$ were female with the two third (75\%) of the inmates ages falls between $30-50$ years, $20 \%$ of the respondent falls below 30 years and $5 \%$ above 50 years. The result also revealed that majority of the inmates (77\%) falls under ATP, $16 \%$ of the inmates have a long term sentence, $6 \%$ has short term sentence and $1 \%$ has a Lifer. This confirms the reports of the prevailing situation of majority of the prisons in Nigeria. The administration of criminal justice in Nigeria constitutes a major cause of the increasing number of awaiting trials inmates, thereby creating congestion in the prison [14]. This was justified by a higher percentage of the inmates (97\%) affirming that the criminal justice system in Nigeria resulting to awaiting trial and delay justice are the factors contributing to the problem of overcrowding of the prisons. Consequently, we can state that the judicial system has not been effective and efficient in the discharge of their responsibility.

Furthermore it was also observed that $89 \%$ of the inmates indicated that the Nigeria Police Force has contributed to congestion of the prisons and this often results into the untimely death of most inmates. This was supported in the report by Amnesty that the police do not bring suspects promptly before a judge or judicial officer; despite the Nigerian Constitution's guarantee that this must occur within 24 hours. Often time, it usually takes weeks or months before suspects are brought before a judge. In addition, suspects are usually starved, illtreated and denied their right to contact their families or a lawyer. The consequence of congestion in the prisons has a negative impact on the welfare of the inmates. $93 \%$ of the inmates affirmed that congestion of the prisons often have a negative impact on the Health of the inmates, expose them environmental Hazard and lead to untimely death. This was justified in the report by Amnesty International [8] which revealed that the living condition caused by overcrowding of most Nigerian prison have a damaging effect on the physical and mental well-being of the inmates and in many cases leads to untimely death. Furthermore, the study showed that prison reforms are cushion towards alleviating the problems of the inmates and to improve the facilities of the prisons and welfare of the inmates. A higher percentage of the inmates (63\%) indicated that the establishment of more prisons and (91\%) indicated the granting of amnesty by state government would improve the welfare of the inmate. The result indicates that prison reforms have a significant impact on the welfare of the inmates.

In this research work, two hypotheses earlier stated were tested and the result showed that delay justice has a significant impact on prison congestions in Nigeria and that prison reforms have a significant impact on the welfare of the inmates in Nigeria. At 0.05 level of significance with 4 degrees of freedom the chi square table figure for hypothesis One (1) was 9.488 while the chi-square calculated value $\left(\mathrm{X}^{2}\right)$ was 10.017 i.e. $\mathrm{X}_{\mathrm{c}}^{2}>\mathrm{X}_{\mathrm{t}}^{2}$ at 0.05 level of significance with 4 degrees of freedom. Therefore the Null hypothesis (Ho) which states that Delay justice has no significant impact on prison congestions in Nigeria is rejected and the alternative hypothesis $\left(\mathrm{H}_{1}\right)$ is accepted. This means that delays in justice have a significant impact on prison congestions in Nigeria. The result of the hypothesis tested revealed that there is a significant relationship impact of delay justice on prison congestion in Nigeria. For Hypothesis Two (2), the chi square table figure was 9.488 while the calculated value $\left(\mathrm{X}^{2}\right)$ was 10.879 . Therefore the Null hypothesis $\left(\mathrm{H}_{\mathrm{o}}\right)$ which states that Therefore the Null hypothesis $\left(\mathrm{H}_{\mathrm{o}}\right)$ which states that Prison reforms has no significant impact on the welfare of the inmates in Nigeria is rejected and the alternative hypothesis $\left(\mathrm{H}_{1}\right)$ is accepted. The result of the hypothesis tested revealed that there is a positive impact of prison reforms on the welfare of the inmates in Nigeria.

\section{Conclusion}

Congestion constitutes a major problem creating a negative effect on the welfare of the inmates in the Nigeria prisons. This is being attributed to poor administration of criminal justice in Nigeria and unethical activities of the Nigeria Police which has constantly threatened the physical, mental and social well-being of the inmates. Consequently, the Nigeria prison has failed to achieve its major role of rehabilitation and reformation of inmates but rather the scenario has been that of dehumanizing situation and hardening of the inmates. Several writers have identified congestion as a major problem facing 
Citation: Opafunso ZO, Adepoju OO (2016) Prison Reforms System and Inmate's Welfare in Nigeria. Arts Social Sci J 7: 166. doi:

Page 6 of 6

the Nigeria prisons which has exposed the inmates to improper health conditions, claimed the lives of some inmates and put enormous pressure on prison infrastructure .In addition, the non-implementation of prison reforms by several presidential commissions and committees can be indicted of the increasing number of inmates awaiting trials. The study revealed that a higher percentage of the inmates are awaiting trial and congestion is a typical problem of the prisons which has a negative effect on the welfare of the inmates. In addition, the findings showed that delay justice contributed to the problem of congestion and that urgent solution is needed to alleviate this problem of the Nigeria prisons. Therefore, the study concludes that the government needs to expedite action in ensuring the implementation of the recommended prison reforms which will address decongestion of the prisons, establishment of more prisons, and the upgrading of existing ones in order to improve the welfare of the inmates. Based on the research findings, the following recommendations were made:

- The government should ensure the implementation of the previously recommended prison reforms which include granting of more amnesty to prisoners whose offences are pardonable.

- The government should ensure that the Minister of interior supervises constantly the prisons and adequate funds should be provided to cater for the needs of the Nigeria Prison Service.

- The government should provide the needed infrastructures and facilities that will cater for the welfare of the inmates.

\section{Acknowledgement}

The contribution of Mr. Adeniji Emmanuel Gbenga is hereby acknowledged in the area of technical data collection.

\section{References}

1. McCorkle L, Korn R (1954) Resocialization within walls. The Annals of American Academy of Political Science 293: 88-98.

2. Okeke T (2010) Prison Fact Sheet. National Assembly Legislative Digest.

3. Onike R (2010) Imperative of Prison Reform. Focus Nigeria.

4. Ogwezzy M (2011) From reformation to deformation: an approach towards sustainable development of the defective prison system in Nigeria. Journal of Sustainable Development in Africa 13: 269- 283.

5. Ibrahim Z (2012) Nigerian Prisons: Death Traps or Reform Centers p: 26.

6. Amnesty International (2012) The State of the Nigerian Prisons. Amnesty International Press pp: 16-17.

7. Ogundipe AO (2011) Prison Amendment in Nigeria, Abuja. Federal Government of Nigeria pp: 28-40.

8. Amnesty International (2008) Nigeria Criminal Justice System Utterly Failing Nigerian People. Amnesty International Press Release pp: 28-29.

9. Njoku C (2012) Reforming the Nigerian Prisons.

10. Obioha $\mathrm{E}$ (2011) Challenges and reform in the Nigeria prison system. J Soc sci 27: 95-105.

11. Achu AA, Owan EJ, Ekok OC (2013) The impact of prison reform on the welfare of Inmates. A case study of Afonkong prison Calabar, Cross River State, Nigeria. Global Journal of Human social science sociology and culture 13: 1-7.

12. Aduba N (2012) Nigeria Prison Service Reform Agenda: Far from Reality pp: 12-13.

13. National Assembly Legislative Digest (2010) National Brief Congestion and Prison Reform Agenda: Reality or Myth. A Publication of the National Assembly pp: 26-28.

14. Ogundipe AO (2012) Congestion of Prisons. Prison News Journal 7: $20-22$. 